\title{
Api-tourism: transforming Slovenia's apicultural traditions into a unique travel experience
}

\author{
I. Kline Arih \& T. Arih Korošec \\ Aritours Travel Agency, Slovenia
}

\begin{abstract}
As a uniquely fresh approach to sustainability, api-tourism represents a new dimension in travel in which beekeeping, as a way of life, is intertwined with a desire to discover the natural and unique in the exchange of knowledge and experience. In Slovenia, socially, economically and environmentally responsible tourism is not merely an option, but a precondition for the further growth of the sector. Awareness of this has prompted two Slovenian partners from the private and public sectors to co-create a range of api-tourism products under the ApiRoutes brand as a fusion of green destinations, apiculture and travel. Concordant with the healthy eco-friendly trends which favour sustainable development, api-tourism demonstrates the transformation of a country's natural wealth and cultural heritage into an authentic travel experience as well as a most promising economic activity. This perspective is illustrated by several examples of good practice described herein. Slovenia is the first - and as yet the only country to certify its api-tourism providers. Further to this, such an innovative niche product illustrates the importance of an advanced marketing strategy which communicates shared values and shared experiences with the intention of building powerful emotional connections between the brand and the consumer. Api-tourism development enjoys the strong support of the SPIRIT Slovenia development agency, the Slovenian Tourist Board as well as the country's Ministry of Agriculture and the Environment, and the Ministry of Foreign Affairs. Slovenia's pre-eminence in this sector is further confirmed through its global role of api-tourism co-ordinator within Apimondia - the International Federation of Beekeepers' Associations.

Keywords: beekeeping tradition, apiculture, api-tourism, well-being, responsible travel, sustainable tourism, Slovenia.
\end{abstract}




\section{Introduction}

Co-developed by Aritours travel agency and the Slovenian Beekeepers' Association, ApiRoutes are branded api-tourism products intended for those who care about bees and the environment, respect life's diversity and want to experience the miscellany of Slovenia's nature and culture. By way of these objectives they provide insight into the unique qualities of this country's living heritage as well as many facets of life in this "Green Piece of Europe". Moreover, in their presentation of innovative api-therapeutic treatments within a typical Slovene bee house, as well as in their depiction of a land rich in apiculture and with a remarkable beekeeping history, such tours lean on timehonoured traditions and unique practices that yield superior honey and a wealth of other products from the hive. In its incorporation of tours and training programs both for professional beekeepers and the novice, api-tourism products are formulated for specific interest groups and the general public alike. The overall aim is to raise awareness as to the importance of bees to mankind, enrich knowledge as to the use and effects of bee products and apitherapy, as well as enhance health and well-being. Such experiences inform and educate as to the importance of the preservation of the natural milieu and cultural heritage, whilst through its promotion of the concept of environmentally and socially responsible travel, api-tourism significantly contributes to the health and well-being of all participants, as well as further enhances the concepts of ecotourism and sustainable development. Sustainable Travel International, Responsible Travel Report [1] mentions recent United Nations research suggesting that in addition to it being an appropriate response to the increasing public demand for greener tourism, investment in sustainability reduces the costs of energy, water and waste, as well as advances notions as to the value of biodiversity, ecosystems and cultural heritage.

\section{In pursuit of responsible travel and authentic experience}

New social trends, together with the popular quest for health and wellbeing, an active life, spirituality, new knowledge and harmonious relationships, dictate innovative approaches to the creation of travel experiences. When asking "Where do we want to go?" we need to reflect on "What experiences are we looking for?" a process that directs us, and may even precipitate a change in our lives. A life enriched by encounters which make us more demanding of ourselves, more responsible towards the environment, and which allow us to contribute more to the community, shall surely make us more generous, as well as happier better people with each passing day. Api experiences, as very fresh and innovative approach to sustainable tourism, weave a narrative dedicated to the individual and their enjoyment of life and the world that surrounds them. Through its provision of insight into an individual's personality, their values, principles, interests, wishes and even dreams, api-tourism offers the visitor adventure, experience and a deal of insight and understanding. 
Legorburu and McColl [2] draw attention to the crucial nature of a focus on the consumers' expectations as well as an assessment as to future behaviour. Api-tourism promotes social responsibility by creating unique travel experiences that encourage mutual understanding, social integration and education. Through this it contributes to quality of life by improving health, life balance and relationships. The environmental orientation is likewise expressed in ApiRoutes products and services that preserve the natural milieu, raise awareness and educate as to the importance of nature conservation and the respect of natural laws.

\section{Api-tourism as a unique product}

\subsection{Advanced practices based on a great tradition}

As a consequence of its lying at the juncture where Mediterranean, Alpine and Dinaric lands converge with the Pannonian Plain of Central Europe, Slovenia enjoys extraordinarily varied landscape as well as a rich diversity of species. Forests occupy approximately $62 \%$ of the total territory, about twice the OECD average. Climate and topography gave rise to a wealth of flora, including some important nectar-bearing plants; as a consequence apiculture, one of this nation's oldest and most traditional rural activities, became an important element of Slovenian culture as well as a major beneficent influence on the development of agriculture. Indeed, it was nearly 250 years ago that the indigenous know-how of small Carniolan farmer-beekeepers was introduced to the world through the works of Anton Janša (1734-1773), who became the first teacher of beekeeping at the Imperial Court in Vienna. Thanks to Janša, such knowledge was disseminated throughout the Habsburg Empire and beyond.

Slovenia is also home to the most gentle and hard-working Carniolan bee (Apis mellifera carnica), first described in 1857 by beekeeper Filip Rothschütz, from Višnja Gora near Ljubljana. The Carniolan bee is the pride of Slovenian apiculturists and acknowledged as something of a national role model. Šivic [3] described that its characteristics - such as diligence, organization, tranquillity and moderate consumption - have endowed the Carniolan bee with a reputation that extends far beyond the country's borders. Indeed, the international trade in these bees - and the queens in particular - has ensured that the Carnie spread all over the world.

Many other internationally respected pioneers of apiculture - such as Dr. Filip Tertsch, the father of modern apitherapy - were born or worked in Slovenia. They laid the foundation stones of the extensive beekeeping heritage which Slovenia enjoys today, and it has been through their endeavours that Slovenes were made aware as to the important role of bees in the environment, as well as the significance of apiculture in rural development and human health. 


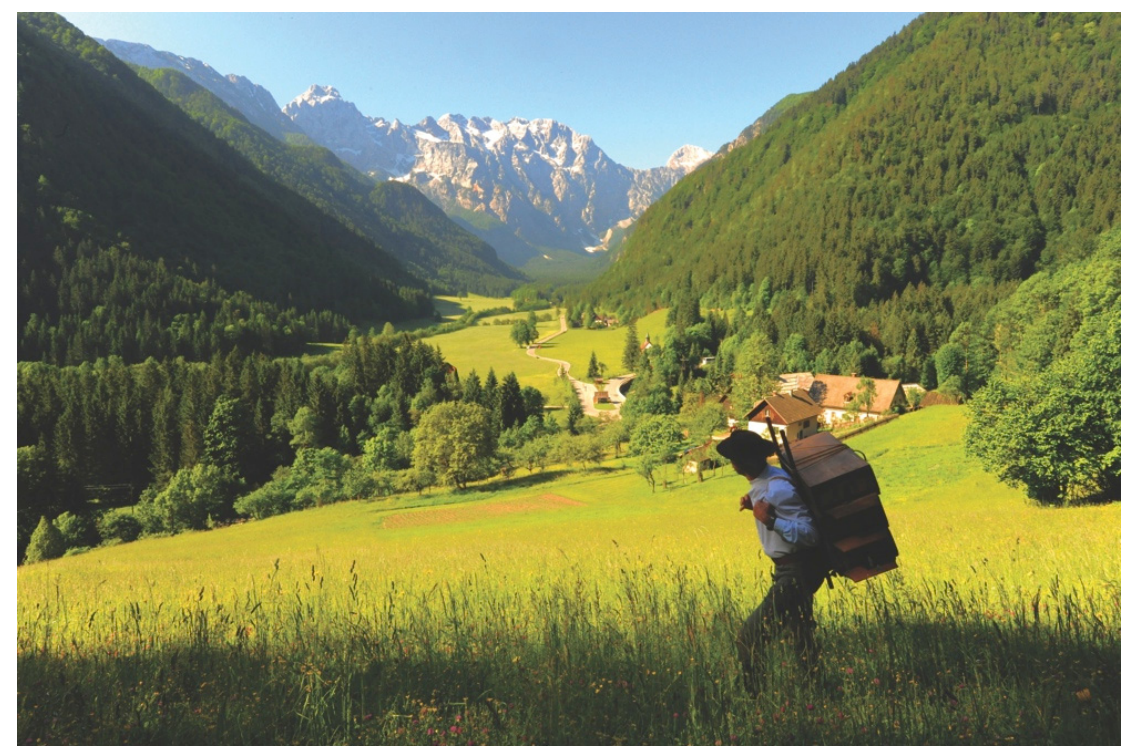

Figure 1: Slovenia's unspoilt nature and great beekeeping tradition.

Hacek and Pickel [4] state that Slovenia's natural endowment has been enhanced by a tradition of close-to-nature forestry and low-intensity farming. Accordingly, beekeeping is considered to be the poetry of agriculture: not merely keeping bees for their honey, but much more...it is a way of life. Noč [5] describes his pride in the soul of Slovenian beekeepers, gently transmitting their knowledge and unique practices from one generation to the next. Just how important apiculture remains in this era of mass urbanisation, is revealed through the statistics: one in every two-hundred Slovenes are apiarists: over 9,600 beekeepers tend some 12,500 apiaries and nearly 170,000 hive colonies. Thus far Slovenia is the only EU member state to have protected its native bee by a law which prohibits the introduction and breeding of any other bee subspecies.

\subsection{Key perspectives of api-tourism}

The ambitions of Slovenian api-tourism promoters and service providers can be summarized in the following objectives: the preservation of tradition in harmony with nature; the provision of education and the creation of new dimensions and experiences in travel and tourism; raising awareness as to the importance of bees to mankind, an objective which includes the promotion of natural products and natural medicines; the development of the green economy in conjunction with environmentally, socially and economically sustainable tourism; the creation of tourist products based on natural advantages, innovation and high added value; the promotion of Slovenia as a country of unique natural and cultural heritage, hospitable people and rich apiculture. 
The philosophy underlying api-tourism is based on adherence to the traditions of symbiosis with nature, as well as the fact that the importance of bees can be mapped to the function of man and his application of such values as loyalty, organization, diligence, respect and harmony.

\subsection{Api experiences: examples of good practice}

Api-tourism, as a new branch of tourism in Slovenia, started to develop in 2007 as a "natural" opportunity for Slovenian beekeepers and operators in the tourism sector to develop a variety of products and services. Šivic [3] states that because it is pre-eminently nature-friendly and sustainable, api-tourism offers visitors an encounter with Slovenia's distinctive and unique apiculture, heritage and natural beauty.

Highlights include observations of beekeepers at their work, introductions to apiarian techniques focusing on biodynamic beekeeping which respects the colony's natural integrity, demonstrations of various hive systems, presentations of bee pollen, royal jelly and propolis production, together with seminars on their beneficent effects on human health and well-being. In addition to visits to beekeeping museums and typical Slovenian bee houses, which are architecturally unique and of extraordinary appeal, Api-tourism provides opportunities to attend professional seminars, round tables and workshops addressing topics ranging from Carniolan queen breeding, various beekeeping methods, the manufacture of items from beeswax and beehive panel painting, to making and baking delicious honey dough dishes and sampling sparkling meads. Further to an exploration and celebration of Slovenia's rich culinary tradition, visitors can experience apitherapy in a typical Slovenian bee house, enjoy an invigorating honey massage or indulge themselves with thermotherapy.

The experience of co-creation, such as painting motifs for beehive front panels or making beeswax decorations is a very important aspect of api-tourism. In her model of sustainable creative tourism, Korez-Vide [6] asserts that in the $21^{\text {st }}$ century, creativity is an important tool in attaining sustainability through competitiveness.

\subsubsection{Beekeeping museums, open-air galleries and apiary classes}

Many beekeeping museums in Slovenia contain excellent collections of traditional equipment and bee-related art, such as the decorated beehive front panels. The smooth wooden panels decorated with fascinating images and themes turn simple bee houses into veritable open-air art galleries; at the same time, the Slovenian apiary can also serve as an experiential outdoor classroom. In addition to workshops on cooking and baking with honey, a variety of activities may be held in and around the bee house, from learning about the secret life of bees and observing the process of honey production, to harvesting honey, cooking wax, comb wiring, as well as obtaining propolis and royal jelly. 


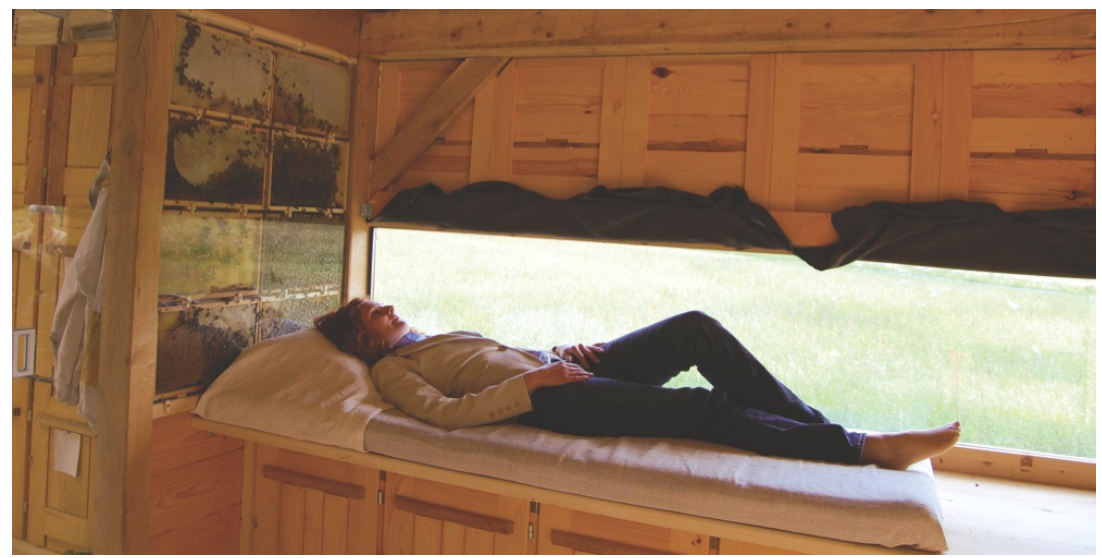

Figure 2: Apitherapy in a typical Slovene bee house.

\subsubsection{Apitherapy and biodynamic beekeeping techniques}

The hive fragrance, which beekeepers inhale while working or resting in the bee house, is most pleasant and beneficent. Šivic [7] states that the free circulation of aromatic air from the hives, engenders an extremely favourable microclimate within the bee house, which exerts a beneficent effect on the human respiratory system and well-being in general. Thus some beekeepers place beds within the bee house, thereby transforming it into an api-therapeutic chamber. Kapš [8] believes pollen allergies can be cured through the regular and timely inhalation of air from beehives. Bio honey massage, aromatherapy and beeswax thermotherapy are proven to be beneficial, especially when carried out within the bee house. Heat, for example, relaxes and accelerates blood circulation, while the skin absorbs nourishing and nurturing substances from the wax which makes it very soft. Likewise, it is well known that beekeepers, prone to being stung, are less prone to various rheumatic ailments, largely because of their exposure to bee venom. Today apitherapy is a widely-established discipline, serving as a beneficial supplement to traditional medicine.

\subsubsection{Honey, honeybread and other bee products}

In November 2013, Slovene honey became the country's $19^{\text {th }}$ product to receive EU protection through its being entered in the register of protected designations of origin. High quality is characterized by its containing less than $18.6 \%$ water as well as having an HMF (Hydroxy-Methyl-Furfuraldehyde) content below $15 \mathrm{mg} / \mathrm{kg}$.

In addition to sampling the huge variety of Slovene floral and honeydew honeys, this country boasts a plethora of creative and aromatic honey drinks including mead, honey liqueur and an effervescent sparkling masterpiece made using the classic Champagne method and conditioned in the bottle. 
Tours, which provide opportunity for the visitor to sample these delicacies, also encompass the memorable experience of a visit to a remarkable bakery which has been making traditional Slovene honey-bread hearts, known as lect, since 1766. In this living museum one can observe skilled confectioners using time-honoured tools and skills to produce honey pastries and other sweet surprises in accordance with traditional recipes.

\subsubsection{Api-training}

Novice beekeepers, together with those with no previous knowledge but who are interested in beekeeping may engage in one or more of the many api-training programmes. In addition to attending practical workshops "live in the hive" guests are offered experience in best practice and may learn about new as well as local developments in beekeeping, including theoretical and practical presentations of sustainability, population growth, queen breeding, extracting propolis and bee pollen, using the A-Ž hive, collecting royal jelly and other products of the hive.

\subsubsection{Carniolan bee breeding}

Šivic [3] states Emil Rothschütz's 1857 article in the German magazine Die Bienenzeitung first drew broader attention to the Carniolan honeybee, and it was this widespread interest that led to its eventual rise in popularity among European beekeepers. Today, selection activities pertaining to the Carniolan honeybee are carefully planned and managed by the Slovenian Beekeepers' Association in close co-operation with Agricultural Institute of Slovenia, both of which act as breeding authorities on behalf of the state. Selection is primarily aimed at preserving the breed and its characteristic gentle character; it also aims to improve productivity in terms of increased activity and the amounts of honey harvested, as well as to ensure the population becomes less prone to swarming. Under the close supervision of the aforementioned breeding authorities, Carniolan queens are today reared by some thirty Slovenian breeders.

\subsubsection{Slovenian Beekeeping Centre}

Home to one of the world's most advanced, best organized and experienced fraternities of beekeepers, the Slovenian Beekeeping Centre hosts the headquarters of the Slovenian Beekeepers' Association, the national advisory service as well as the offices of the Slovenski Čebelar magazine; there is also a laboratory, specialist library and shop selling beekeeping equipment and products. In addition to the architectural beauty of the Centre itself, the immediate vicinity is also of interest. In front, there's a plantation of nectarbearing and medicinal plants, while a trail leads one to three beautiful bee houses in the unique Carniolan style. The Centre is today a focal point for innovation and development, and there is a great deal which is of interest hereabouts, including the most recent applications in api-therapy, as well as the use of some types of honey in the prevention and healing of periodontitis. 


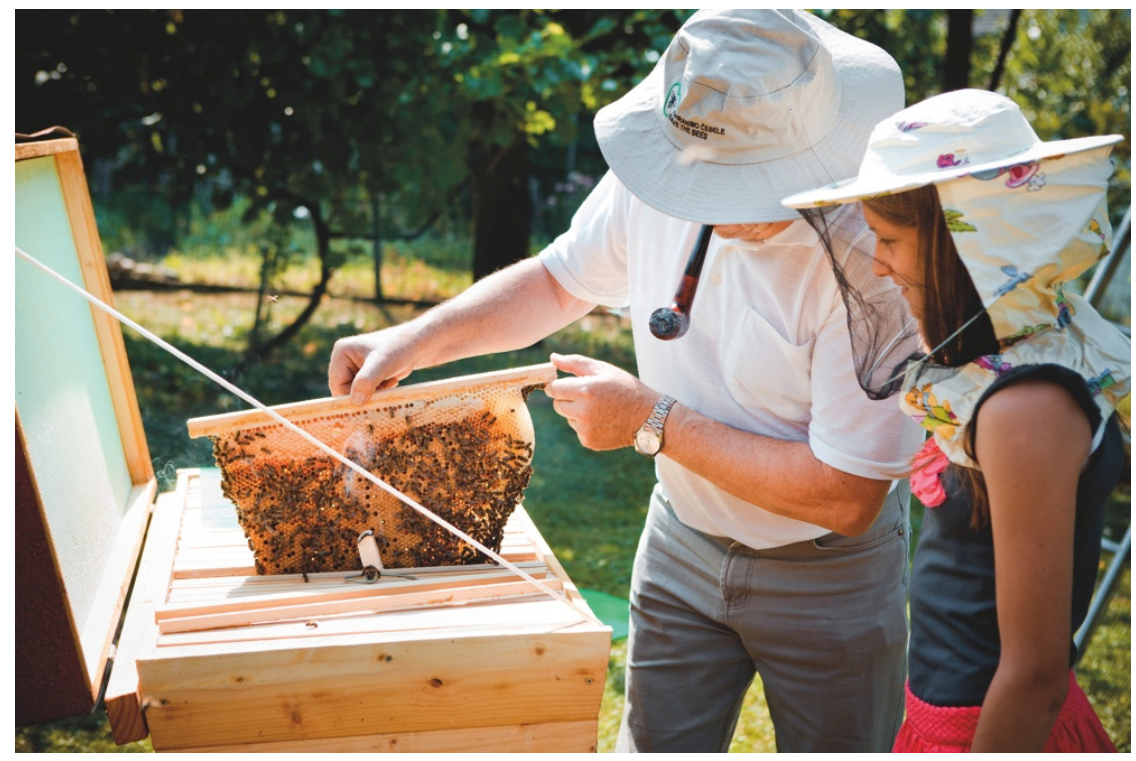

Figure 3: Raising awareness as to the importance of bees to mankind.

\subsection{Ambassadors of health and education}

As initiator of the Traditional Slovenian Breakfast in this nation's kindergartens and primary schools, the Slovenian Beekeepers' Association aims to extend this seven-year-old campaign across the whole of Europe [9]. The concept underlying this project has been to raise awareness as to the importance of bees, bee products and a healthy lifestyle, as well as the significance of selfsufficiency, traditional foods and local sourcing and production in the public procurement system. By way of such programmes young people are encouraged to eat healthily as well as introduced to the importance of agriculture, beekeeping and food from the local environment. The Slovenian Beekeepers' Association wishes to see its initiative implemented not merely in the education system but more universally, and in as many European countries as possible.

In December 2013, Aritours became Co-ordinator of the Apimondia, International Federation of Beekeepers' Associations Api-Tourism Working Group, a most important and challenging initiative. On the basis of extant natural and cultural resources, shared knowledge and transnational initiatives in common projects, Ratia [10] anticipates that this initiative shall take a leading role in promoting and encouraging the development of api-tourism worldwide.

In relation to organisation, craftsmanship, production and service provision, the Api-Tourism Working Group shall enable the sharing of experiences as well as the exchange of examples of best practice from around the world. Firstly, it will examine the conditions and traditions that form a basis for the potential development of api-tourism; after which it shall evaluate the various approaches 
taken. Upon completion of these preparations, the Working Group will assist with the application of strategies and guidelines intended to motivate all those interested in the development of api-tourism in order that they may play an active role in trans-national activities and co-operation.

\section{Api-tourism certificate of excellence}

One of the trends in green tourism is the application of such epithets as local, indigenous bio, eco, organic and healthy, and such labels are also applied to apitourism in Slovenia. The holistic approach to responsible tourism categorises experiences according to their impact on the environment, culture and community. Further to this, Slovenia is the first - and as yet the only - country to certify its api-tourism and api-therapy providers, and assessment as to their specialisation and orientation is currently underway. In most cases these providers encompass beekeepers who are target-oriented in their exploitation of opportunities in eco-apiculture, biodynamic apiculture, as well as beekeeping using various beehive systems. In addition, api-tourism also embraces other institutions, artisans and service providers, including, queen bee breeders, beekeeping ethnography collections, open-air museums and beekeeping education routes, api-therapists, beehive front panel painters, honey confectioners, beeswax candle-makers, honey-bread and honey-pastry bakers, honey beverage producers, natural api-cosmetic and care product makers, bespoke and specialist gift makers as well as many others. In their provision of local produce and innovative wellness packages, some also offer food and accommodation to tourists, as well as the possibility to engage in sport and recreational activities, including horse riding, trekking and hiking.

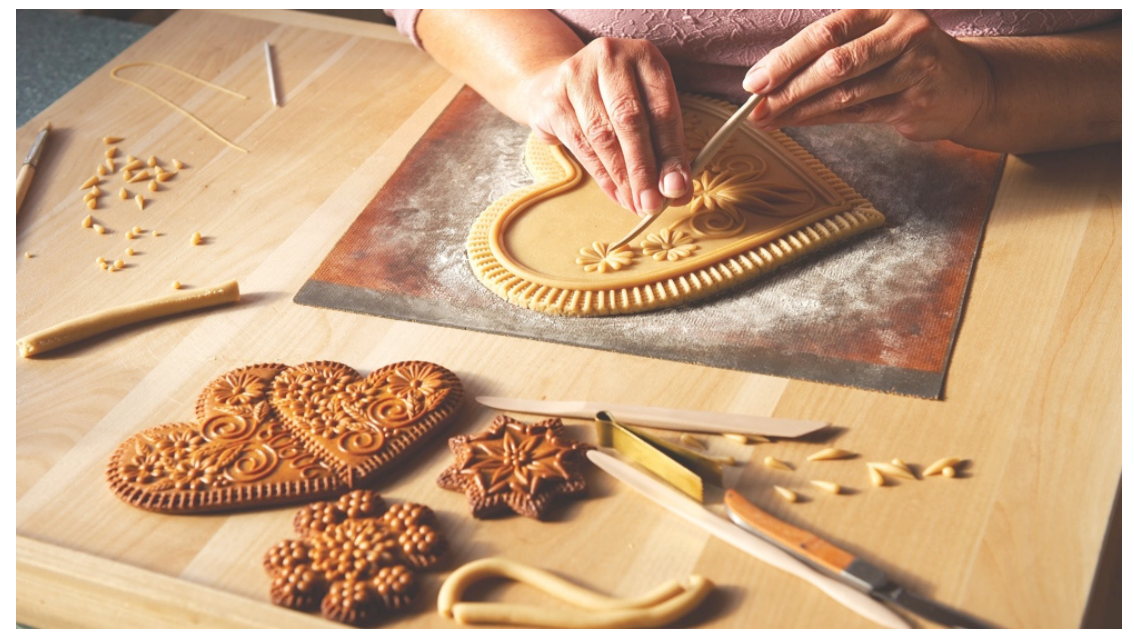

Figure 4: Honey-bread workshops as a creative component of api-tourism. 
One, two or three bees in a symbol indicate individual providers according to the quality and attraction of their services, their use of nature-friendly materials, specialisation, innovation, efficiency, experience and setting. In addition to controlling the content and implementation of services, certification is an element of the utmost importance in the promotion of excellence and innovation in the development of api-tourism, due to the very fact that it has an impact on the promotion of quality and competitiveness.

\section{Policymaking in the development of api-tourism}

Slovenia's 2012-2016 tourism development strategy [11] seeks to promote the country as an attractive, active and healthy destination. This strategy is predicated on the belief that through the generation of revenues and the creation of employment, sustainable tourism will play an increasingly important part in this country's socioeconomic development. On the basis of the creation of a favourable business environment, as well as the formulation and intensive marketing and promotion of sustainable high value added tourist products, Slovenia's tourism sector will become ever more innovative and efficient. By way of this, as well as through its creation of internationally recognized brands, Slovenia's reputation as an alluring tourist destination will rise, as will tourism's commensurate contribution to the national economy.

Slovenia's Ministry of Agriculture and the Environment has invested a lot of effort and resources into apiculture over recent years. Of late Slovenia has witnessed the realisation and development of previously untapped potentials in relation to the production and processing of hive-related products. There exists opportunities for apiarists to create employment as well as realize their entrepreneurial ideas in symbiosis with beekeeping. Value-added activities have been discernible not just with regard to honey, but also in relation to the development of dietary, healthcare and cosmetic products, as well as in the provision of complementary services such as apitherapy and tourism. Through the creation of new paradigms and endeavours in apiculture, beekeeping continues to contribute to ensuring the vitality and visibility of Slovenia's rural economy.

Hacek and Pickel [4] draw attention to Slovenia's creation of a comprehensive framework of primary environmental legislation over the last decade; indeed, most EU environmental directives were transposed into the 2004 Environmental Protection Act RS. The country has also adopted new and revised environmental quality and emission standards as well as made good progress in creating a multi-tier system of environmental permit granting. It has introduced risk-based planning into environmental assessment as well as improved compliance monitoring and enforcement. Slovenia's commitment to sustainable development, both nationally and internationally, is articulated through various co-operation agreements covering the Alps, Danube Basin and AdriaticMediterranean regions. Slovenia has concluded bilateral water management agreements with neighbouring states (Croatia, Hungary and Italy), as well as a spatial planning in border regions agreement with Austria. 


\section{Conclusions}

International Tourism Partnership [12] states the market for more socially responsible tourist products and services is a growing one. Api-tourism, as a novel concept in travel and holidaying, has emerged and developed into an important component of the green economy. On the basis of innovation and high value-added, such tourist products leverage other competitive advantages. The role model provided by api-tourism in Slovenia draws attention to the importance of preserving natural resources and cultural heritage. It also points to the advantages of nurturing traditions and - through the application of a development strategy - the ability to convert distinctive ethnographic characteristics, comparative advantages and know-how into economically viable, socially responsible and environmentally sustainable tourism products which promote social responsibility and conservation as well as meet the expectations of the modern tourist.

Legorburu and McColl [2] explain that such products have the power to create immersive experiences for those who want to be a part of an actual story, as opposed to merely being sold a brand story. As such api-tourism enjoys the potential to make a tremendous contribution to Slovenia's international reputation. ApiRoutes is demonstrative of the need of having a clear vision, an innovative product and brand, indigenous knowledge, defined markets as well as highly motivated and fully involved partners.

The firm foundation for the successful development of api-tourism is predicated on the establishment of co-operation between beekeepers, associations, tourism providers, local communities, authorities and the state, as well as through partnerships aimed at developing, positioning and marketing products and services. Api-tourism enjoys great potential as an additional opportunity to augment and consolidate the position of beekeepers in a niche tourism market. With its educational role, such tourism brings out the best in destinations and services, the best in people, the best in their perceptions and actions, and it transforms all this awareness and knowledge into an important value to take home, share and live by.

Goodwin [13] claims that realising sustainable tourism is a vital global necessity. It is a hugely important challenge to those who organise and market travel and tourism, and those who consume it. Taking Responsibility for Tourism is not a book about a niche product; major trade associations and large and small tour operators are shouldering their responsibilities and committing to the objectives of responsible tourism.

\section{References}

[1] Sustainable Travel International, Responsible Travel Report, http://www.responsibletravelreport.com/trade-news/spotlight/42-tradenews/2719-demand-for-responsible-travel-strong-growing-and-profitableconcludes-new-analysis-by-center-for-responsible-travel, accessed 4.6.2014. 
[2] Legorburu, G. \& McColl D., Storyscaping, Stop creating ads, start creating worlds, John Wiley \& Sons, Inc., New Jersey, pp. 83-89, 2014.

[3] Šivic F., Apitourism - A fusion of apiculture and tourism in Slovenia, Bee World, Volume 90, Issue 3, IBRA, Treforest, pp. 66-67, 2013.

[4] Hacek M. \& Pickel S., SGI Sustainable Governance Indicators, 2014 Slovenia Report, Bertelsmann Stiftung, p. 11, 2014.

[5] Noč B. Personal Communication, 30. July 2013, President, Slovenian Beekeepers' Association, Brdo pri Lukovici, Slovenia.

[6] Korez-Vide, R., Innovative Issues and Approaches in Social Sciences, Vol. 6, No. 1, Promoting sustainability of tourism by creative tourism development: How far is Slovenia?, http://www.iiass.com/pdf/IIASS2013-no1-art05.pdf, accessed 8.6.2014.

[7] Šivic F., Living with bees, Ministry of agriculture, forestry and food, Republic of Slovenia, Ljubljana, p. 34, 2003.

[8] Kapš, P., Zdravljenje s čebeljimi pridelki, apiterapija (Eng. Treatment with bee products, Apitherapy), Grafika Tomi, Novo mesto, p. 168, 2012.

[9] http://www.slovenia.info/en/news-items/Beekeeping-tourism-in-Slovenia. htm?news_items $=2686 \& l n g=2$, accessed 5.6.2014.

[10] Ratia, G. Personal Communication, 12. December 2013, President, Apimondia, International Federation of Beekeepers' Associations.

[11] 2012-2016 Slovenian Tourism Development Strategy, http://www.slovenia.info/pictures\%5CTB_board\%5Catachments_2\%5C20 12\%5C2012-2016_SLOVENIAN_TOURISM_DEVELOPMENT_ STRATEGY_(summary)_14629.pdf, accessed 10.6.2014.

[12] International Tourism Partnership, https://www.hotel-yearbook.com/ download/152005244.pdf?check=07418, accessed 4.6.2014.

[13] Goodwin, H., Taking Responsibility for Tourism, The International Center for Responsible Tourism, http://www.icrtourism.org/publications/book/, accessed 4.6.2014. 